\title{
The relative validity and repeatability of an FFQ for estimating intake of zinc and its absorption modifiers in young and older Saudi adults
}

\author{
Hadeil M Alsufiani ${ }^{1,2, *}$, Fatmah Yamani ${ }^{3}$, Taha A Kumosani ${ }^{2}$, Dianne Ford ${ }^{1,4}$ \\ and John C Mathers ${ }^{1,5}$ \\ ${ }^{1}$ Human Nutrition Research Centre, Newcastle University, Newcastle upon Tyne, UK: ${ }^{2}$ Faculty of Science, \\ Biochemistry Department, King Abdulaziz University, PO Box 50981, Jeddah 21533, Saudi Arabia: ${ }^{3}$ Faculty of \\ Medicine, King Abdulaziz University, Jeddah, Saudi Arabia: ${ }^{4}$ Institute for Cell and Molecular Biosciences, Medical \\ School, Newcastle University, Newcastle upon Tyne, UK: ${ }^{5}$ Institute for Ageing and Health, Newcastle University, \\ Newcastle upon Tyne, UK
}

Submitted 19 August 2013: Final revision received 19 May 2014: Accepted 22 June 2014: First published online 11 August 2014

\begin{abstract}
Objective: To assess the relative validity and repeatability of a sixty-four-item FFQ for estimating dietary intake of $\mathrm{Zn}$ and its absorption modifiers in Saudi adults. In addition, we used the FFQ to investigate the effect of age and gender on these intakes.

Design: To assess validity, all participants completed the FFQ (FFQ1) and a $3 \mathrm{~d}$ food record. After 1 month, the FFQ was administered for a second time (FFQ2) to assess repeatability.

Setting: Jeddah, Saudi Arabia.

Subjects: One hundred males and females aged 20-30 years and 60-70 years participated.

Results: Mean intakes of $\mathrm{Zn}$ and protein from FFQ1 were significantly higher than those from the food record while there were no detectable differences between tools for measurement of phytic acid intake. Estimated intakes of Zn, protein and phytate by both approaches were strongly correlated $(P<0 \cdot 001)$. Bland-Altman analysis showed for protein that the difference in intake as measured by the two methods was similar across the range of intakes while for $\mathrm{Zn}$ and phytic acid, the difference increased with increasing mean intake. $\mathrm{Zn}$ and protein intakes from FFQ1 and FFQ2 were highly correlated $(r>0 \cdot 68, P<0.001)$ but were significantly lower at the second measurement (FFQ2). Older adults consumed less $\mathrm{Zn}$ and protein compared with young adults. Intakes of all dietary components were lower in females than in males.

Conclusions: The FFQ developed and tested in the current study demonstrated reasonable relative validity and high repeatability and was capable of detecting differences in intakes between age and gender groups.
\end{abstract}

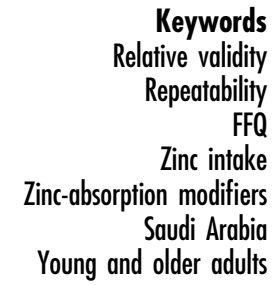

It has been estimated that $\mathrm{Zn}$ binds to 3-10\% of all human proteins. Zn finger proteins, of which the majority are transcription factors ${ }^{(1,2)}$, comprise a large proportion of this total. More than seventy enzymes, including DNA and RNA polymerases, require $\mathrm{Zn}$ as a $\operatorname{cofactor}^{(3)}$. $\mathrm{Zn}$ is therefore essential for numerous cellular functions, including processes as fundamental as nucleic acid synthesis and the regulation of gene expression, along with inflammation ${ }^{(4)}$, immunity ${ }^{(5)}$, bone metabolism ${ }^{(6)}$, taste perception ${ }^{(7,8)}$, spermatogenesis ${ }^{(9)}$, skin health ${ }^{(10)}$ and defence against free-radical attacks ${ }^{(11)}$. It has emerged relatively recently that $\mathrm{Zn}$ acts as an intracellular signalling molecule, facilitating communication between cells, conversion of extracellular stimuli to intracellular signals and controlling a host of intracellular functions ${ }^{(12)}$.

$\mathrm{Zn}$ is not stored in the body and, thus, a constant adequate supply of dietary $\mathrm{Zn}$ is required. In man, dietary $\mathrm{Zn}$ is absorbed in the proximal small bowel, the distal duodenum and the proximal jejunum ${ }^{(13,14)}$ and the efficiency of absorption can be affected by the presence of dietary enhancers and inhibitors ${ }^{(15)}$. Higher levels of protein enhance $\mathrm{Zn}$ absorption ${ }^{(16)}$ while phytic acid represses it 
through the formation of insoluble complexes with $\mathrm{Zn}$ in the gastrointestinal tract ${ }^{(17-19)}$. Because human and other higher species do not secrete phytases, phytate-bound $\mathrm{Zn}$ is excreted in faeces ${ }^{(20)}$. Decreased dietary absorption efficiency and/or inadequate $\mathrm{Zn}$ intake contribute to reduced $\mathrm{Zn}$ status and the development of $\mathrm{Zn}$ deficiency at the population level ${ }^{(21,22)}$.

In Saudi Arabia there have been few studies of $\mathrm{Zn}$ intake and $\mathrm{Zn}$ status. However, the limited evidence available suggests that older adults have lower serum $\mathrm{Zn}$ status than young adults ${ }^{(23,24)}$ and that the proportion of free-living elderly males with inadequate $\mathrm{Zn}$ intake (below the Estimated Average Requirement) is higher than among young adults ${ }^{(25)}$. Additionally, low $\mathrm{Zn}$ intakes were found in institutionalized females ${ }^{(26)}$ but not males ${ }^{(27)}$. For freeliving older females in Saudi Arabia, there are no data on intakes of $\mathrm{Zn}$ or of $\mathrm{Zn}$-absorption modifiers. One reason for this evidence gap is the lack of a suitable tool designed specifically for quantifying intakes of $\mathrm{Zn}$ and its absorption modifiers by adults of all ages and both genders in this population group. Most previous studies used either food records (FR) or $24 \mathrm{~h}$ recalls ${ }^{(24,26,27)}$; an exception was Alissa ${ }^{(25)}$. However, these methods require a high degree of cooperation from participants and analysis of data is labour intensive ${ }^{(28)}$. An FFQ may provide an adequate assessment of usual intake and has the benefit that the demand on respondents and researchers is more modest ${ }^{(28)}$. Thus, the aim of the present study was to assess the relative validity and repeatability of an FFQ for estimating dietary intakes of $\mathrm{Zn}$ and its absorption modifiers in Saudi adults. In addition, we aimed to use the FFQ to investigate the effect of age and gender on these intakes.

\section{Materials and methods}

\section{Participants}

One hundred male and female participants aged 20-30 years (younger adults) and 60-70 years (older adults) were recruited from King Abdulaziz University students, staff and their families, via personal contact, by email messages and by telephone. Participants were divided equally into four groups according to gender and age (twenty-five persons per group). The study was conducted according to the guidelines laid down in the Declaration of Helsinki and all participants gave written informed consent.

\section{Assessment of dietary intake}

A previously validated semi-quantitative $\mathrm{FFQ}^{(29)}$ developed in Australia was modified for use in assessing dietary $\mathrm{Zn}$ intake by Saudi adults. Modifications were based on a comprehensive list of foods and drinks consumed by 17892 Saudis obtained in a previous survey ${ }^{(30)}$ and we used $24 \mathrm{~h}$ recall to collect new data on food and drink consumption. Saudi mixed dishes e.g. rice with milk and rice with tomato sauce that contain $\mathrm{Zn}$ in excess of $0.5 \mathrm{mg} / 100 \mathrm{~g}$ of the edible portion ${ }^{(31)}$, according to the food composition tables for Arab Gulf countries, were included in the FFQ developed for the present study. Foods with a high $\mathrm{Zn}$ content but prohibited or rarely consumed by Saudis, e.g. pork, canned fish, raw oysters and quiche, were excluded. Phytate-rich foods (which inhibit the absorption of $\mathrm{Zn}$ ) and protein-rich foods (which enhance absorption) were included in the FFQ. Beef, lamb, liver and chicken are examples of high-Zn and -protein foods in the Saudi diet, while chickpeas, broad beans and falafel (deep-fried bean and vegetable patty) are high in phytic acid. The FFQ collected information on foods eaten alone as well as the same foods when consumed in mixed dishes, e.g. white rice alone and rice with milk (saleeq).

Sixty-four food items were classified into ten categories: (i) meat (eight items); (ii) seafood (four items); (iii) egg (one item); (iv) dairy products (seven items); (v) vegetables (nine items); (vi) fruits (one item); (vii) seeds and nuts (two items); (viii) cereals (nineteen items); (ix) beverages (one item); and (x) miscellaneous (twelve items; Table 1). Relatively simple and unambiguous food items such as egg were placed at the start of the questionnaire since this approach may help study participants to get used to the format of the questionnaire and so decrease reporting errors $^{(32)}$. Food items relatively rich in $\mathrm{Zn}$ such as meats and seafood were placed in the FFQ shortly after egg because the accuracy of participants' responses may decline towards the end of the questionnaire due to fatigue or boredom ${ }^{(32)}$.

For each food item, a standard serving (medium serving) was expressed in commonly used portions such as grams, cups, tablespoons, slices or pieces ${ }^{(25,29)}$. Participants were asked to recall how often, on average, they had consumed each food over the past year and how their usual serving size differed from that of the standard serving (i.e. small or large estimated as 50 and $150 \%$ of the standard serving, respectively). Pictures of food portion sizes were used to aid participant recall ${ }^{(33)}$. The frequency of intake was assessed on an ascending eight-point scale: 'never', 'less than once/month', '1-3 times/month', 'once/ week', '2-4 times/week', '5-6 times/week', 'once/day' and 'twice or more/day'. This scale was used because it covers the usual range in frequency of consumption of foods by Saudis; a few foods such as meat or cheese pie are consumed two to four times weekly, whereas others such as rice and breads are consumed more than once daily. Finally, participants were asked to record any food items that were usually eaten and that were not included in the list. Between 2 and 6 weeks (average 4 weeks) after the first administration of the FFQ (FFQ1), all participants completed the FFQ for the second time (FFQ2) to test its repeatability.

$\mathrm{Zn}$ intake from the FFQ was calculated by multiplying the amount of $\mathrm{Zn}(\mathrm{mg})$ in a medium serving by a serving 
Table 1 Food items (serving size) included in the FFQ

\begin{tabular}{|c|c|c|}
\hline Eggs & Vegetables & White toast ( 1 slice; $25 \mathrm{~g}$ ) \\
\hline Eggs (1 egg) & Potato (1 medium; $150 \mathrm{~g}$ ) & White pasta ( 1 cup; $100 \mathrm{~g}$ ) \\
\hline Meat & Broccoli (1 cup; $80 \mathrm{~g}$ ) & White rice ( 1 cup; $175 \mathrm{~g}$ ) \\
\hline Beef $(120 \mathrm{~g})$ & Spinach, silver beet ( $1 / 3$ cup; $60 \mathrm{~g}$ ) & Rice with milk (saleeq) (1 cup) \\
\hline Lamb (2 chops; $100 \mathrm{~g})$ & Tabouli ( 1 cup; $200 \mathrm{~g}$ ) & Rice with tomato sauce (kabsa) (1 cup) \\
\hline Veal (1 chop; $90 \mathrm{~g})$ & Okra with tomato sauce ( 1 cup) & Rice with lentil (1 cup) \\
\hline Diced meat (kebab or hamburger) $(150 \mathrm{~g})$ & Vegetables, stuffed (1 piece) & Whole meal crisp bread $(1 ; 5 \mathrm{~g})$ \\
\hline Meat shawerma (1 medium sandwich) & Peas ( $1 / 3$ cup; $60 \mathrm{~g})$ & White crisp bread $(1 ; 5 \mathrm{~g})$ \\
\hline Chicken shawerma ( 1 medium sandwich) & Chickpeas (1/2 cup; $200 \mathrm{~g})$ & Rolled oats (boiled) (1 cup; $230 \mathrm{~g}$ ) \\
\hline Chicken (1 breast or thigh; $110 \mathrm{~g}$ ) & Broad bean (1/2 cup; $100 \mathrm{~g})$ & Fruit cake/loaf ( 1 slice; $75 \mathrm{~g}$ ) \\
\hline Liver (3/4 cup; $150 \mathrm{~g})$ & Fruits & Muffin $(1 ; 55 \mathrm{~g})$ \\
\hline Seafood & Citrus fruits ( 1 piece) & Biscuits (bran, whole meal) $(1 ; 20 \mathrm{~g})$ \\
\hline Fish (whole; 1 fillet; $120 \mathrm{~g}$ ) & Beverages: Cocoa & Miscellaneous \\
\hline Oysters (smoked; $1 ; 5 \mathrm{~g}$ ) & Drinking chocolate ( $1 \mathrm{tbsp} ; 9 \mathrm{~g}$ ) & Meat pie (sambosak) (1 piece) \\
\hline Crab/scallops ( $1 / 2$ cup; $90 \mathrm{~g})$ & Seeds and nuts & Cheese pie (sambosak) (1 piece) \\
\hline Lobster/prawn/squid (1/2 cup; $90 \mathrm{~g}$ ) & Sesame butter ( $1 \mathrm{tsp})$ & Meat pie (fatayer) $(160 \mathrm{~g})$ \\
\hline Dairy & Nuts $(15 \mathrm{~g})$ & Cheese pie (fatayer) $(160 \mathrm{~g})$ \\
\hline Cheese (1 slice; $20 \mathrm{~g}$ ) & Cereals & Pizza (150 g) \\
\hline Yoghurt (1 cartoon; $200 \mathrm{~g})$ & Whole grain corn flakes ( $1 \mathrm{cup} ; 30 \mathrm{~g}$ ) & Bean and vegetable patty (tameya, falafel) (3 pieces) \\
\hline Cow's milk ( 1 glass; $200 \mathrm{ml}$ ) & Corn flakes ( 1 cup; $30 \mathrm{~g}$ ) & Popcorn (1 cup) \\
\hline Cow's milk (with cereal) (1/2 cup; $125 \mathrm{ml}$ ) & Brown pita bread ( 1 slice; $25 \mathrm{~g}$ ) & Chips/corn chips/twisties $(50 \mathrm{~g})$ \\
\hline Cow's milk (in tea/coffee) (2tbsp; $40 \mathrm{ml}$ ) & White pita bread ( 1 slice; $25 \mathrm{~g}$ ) & Chocolate (1 bar) \\
\hline Fermented milk (laban) (1 glass; 200 ml) & Brown loaf bread (1 medium size) & Custard (1/2 cup) \\
\hline \multirow[t]{2}{*}{ Ice cream (2 scoops; $60 \mathrm{~g}$ ) } & White loaf bread ( 1 medium size) & Rice with milk and sugar (mohalabeya) (1/2 cup) \\
\hline & Brown toast (1 slice; $25 \mathrm{~g}$ ) & Cream caramel ( $1 / 2$ cup) \\
\hline
\end{tabular}

size factor and a frequency factor. Serving size factors were $0.5,1$ and 1.5 for small, medium and large serving, respectively. The frequency of intake per day was calculated as follows: $0,1 / 60,2 / 30,1 / 7,3 / 7,5 \cdot 5 / 7,1$ and 2 for the eight-point scale, respectively. Total daily absolute $\mathrm{Zn}$ intake for each participant was calculated by summing the intakes from each food item. Phytic acid and protein intakes were calculated in the same way.

An open record of food intake (food record; FR) on two sequential weekdays and one weekend day was used as a reference method for validating the FFQ and was completed in the same week as, but after, the administration of FFQ1. All participants were given instruction about completing the FR. In addition, each participant was provided with a booklet of serving size pictures to aid them in recording the quantity of the foods and drinks consumed. Zn, phytic acid and protein intakes from the FR and FFQ were analysed using the Nutrition Data System for Research software version 2012, developed by the Nutrition Coordinating Center (NCC), University of Minnesota (Minneapolis, MN, USA) after entering the nutritional analysis of Saudi dishes ${ }^{(31)}$.

\section{Statistical analysis}

To assess the validity of the FFQ, differences in mean intake of dietary components between the FFQ and FR were examined by using Student's paired $t$ test. ANOVA was used to test the differences in dietary component intakes between age and gender groups. Correlations between values obtained from the FFQ and the FR were tested using Spearman's correlations because the data distributions were skewed. Bland-Altman analysis was undertaken to investigate the agreement between the two methods for estimating intakes of dietary components. Moreover, cross-classification was used to evaluate the ability of both methods to classify individuals similarly into equal thirds of the distribution of dietary component intake. The cut-off points were determined separately for the FFQ and the FR.

To test the repeatability of the FFQ, the same statistical tests were performed between FFQ1 and FFQ2 with the exception of the cross-classification. Additionally, intraclass correlation coefficients were calculated for each of the dietary components for data from FFQ1 and from FFQ2.

All statistical analyses were performed using the statistical software package IBM SPSS Statistics version 19 with the exception of Bland-Altman analysis, which was performed using MedCalc Statistical software version 12.6.1. Statistical significance was taken as $P<0.05$.

\section{Results}

\section{Study participants}

One hundred volunteers participated in the present study. All completed two FFQ and a $3 \mathrm{~d}$ FR. The majority of the younger participants were healthy while half and a third of the older adults had diabetes and high blood pressure, respectively. The mean BMI was $28.30 \mathrm{~kg} / \mathrm{m}^{2}$. More than $50 \%$ of the participants were non-smokers and $40 \%$ had a high education level (Table 2).

\section{Relative validity}

We assessed the validity of the FFQ by comparing data collected using the first administration of the FFQ (FFQ1) with data from the $3 \mathrm{~d}$ FR. Table 3 shows the mean daily intakes of Zn, phytic acid and protein estimated by FFQ1 and the $3 \mathrm{~d}$ FR. Mean intakes of $\mathrm{Zn}$ and protein from FFQ1 were significantly higher than those from the FR $(P<0.001$ 
Table 2 Characteristics of the study participants; males and females aged 20-30 years and 60-70 years, Jeddah, Saudi Arabia ( $n$ 100)

\begin{tabular}{|c|c|c|c|c|c|c|c|c|c|c|}
\hline & \multicolumn{2}{|c|}{$\begin{array}{l}\text { Young females } \\
(n \text { 25) }\end{array}$} & \multicolumn{2}{|c|}{$\begin{array}{c}\text { Young males } \\
(n 25)\end{array}$} & \multicolumn{2}{|c|}{$\begin{array}{l}\text { Older females } \\
\quad(n 25)\end{array}$} & \multicolumn{2}{|c|}{$\begin{array}{l}\text { Older males } \\
\quad(n \text { 25) }\end{array}$} & \multicolumn{2}{|c|}{$\begin{array}{l}\text { All participants } \\
\quad(n 100)\end{array}$} \\
\hline & $n$ & $\%$ & $n$ & $\%$ & $n$ & $\%$ & $n$ & $\%$ & $n$ & $\%$ \\
\hline Mean age (years) & \multicolumn{2}{|c|}{$25 \cdot 64$} & \multicolumn{2}{|c|}{$22 \cdot 24$} & \multicolumn{2}{|c|}{64.89} & \multicolumn{2}{|c|}{64.64} & \multicolumn{2}{|c|}{ _- } \\
\hline Mean height $(\mathrm{m})$ & \multirow{2}{*}{\multicolumn{2}{|c|}{$\begin{array}{c}1.59 \\
70.88\end{array}$}} & \multirow{2}{*}{\multicolumn{2}{|c|}{$\begin{array}{c}1.71 \\
82.56\end{array}$}} & & 1.57 & \multicolumn{2}{|c|}{1.69} & \multicolumn{2}{|c|}{1.64} \\
\hline Mean body mass $(\mathrm{kg})$ & & & & & \multirow{2}{*}{\multicolumn{2}{|c|}{$\begin{array}{c}77.34 \\
30 \cdot 8\end{array}$}} & \multirow{2}{*}{\multicolumn{2}{|c|}{$\begin{array}{c}76.56 \\
26.6\end{array}$}} & \multirow{2}{*}{\multicolumn{2}{|c|}{$\begin{array}{c}76.89 \\
28.3\end{array}$}} \\
\hline Mean BMI $\left(\mathrm{kg} / \mathrm{m}^{2}\right)$ & \multicolumn{2}{|c|}{$\begin{array}{l}27.9 \\
27.9\end{array}$} & \multicolumn{2}{|c|}{$28 \cdot 0$} & & & & & & \\
\hline \multicolumn{11}{|l|}{ Health status } \\
\hline Cancer & 0 & 0 & 0 & 0 & 0 & 0 & 0 & 0 & 0 & 0 \\
\hline High blood pressure & 0 & 0 & 0 & 0 & 9 & 36 & 8 & 32 & 7 & 7 \\
\hline Heart diseases & 0 & 0 & 0 & 0 & 4 & 16 & 3 & 12 & 7 & 7 \\
\hline Liver diseases & 0 & 0 & 0 & 0 & 0 & 0 & 1 & 4 & 1 & 1 \\
\hline Kidney diseases & 0 & 0 & 0 & 0 & 0 & 0 & 0 & 0 & 0 & 0 \\
\hline Osteoporosis & 0 & 0 & 0 & 0 & 5 & 20 & 3 & 12 & 8 & 8 \\
\hline Arthritis & 0 & 0 & 0 & 0 & 7 & 28 & 2 & 8 & 9 & 9 \\
\hline Diabetes & 0 & 0 & 0 & 0 & 12 & 48 & 13 & 52 & 25 & 25 \\
\hline Lung diseases & 1 & 4 & 0 & 0 & 1 & 4 & 1 & 4 & 3 & 3 \\
\hline Allergy & 2 & 8 & 0 & 0 & 4 & 16 & 0 & 0 & 6 & 6 \\
\hline Gastrointestinal disorders & 2 & 8 & 1 & 4 & 5 & 20 & 6 & 24 & 14 & 14 \\
\hline Cigarette smoking status & & & & & & & & & & \\
\hline Non-smoker & 16 & 64 & 14 & 56 & 16 & 64 & 11 & 44 & 57 & 57 \\
\hline Former smoker & 0 & 0 & 4 & 16 & 3 & 12 & 6 & 24 & 13 & 13 \\
\hline Passive smoker & 6 & 24 & 2 & 8 & 4 & 16 & 2 & 8 & 14 & 14 \\
\hline Smoker & 3 & 12 & 5 & 20 & 2 & 8 & 6 & 24 & 16 & 16 \\
\hline Shisha/argela smokert & 3 & 12 & 8 & 32 & 4 & 16 & 3 & 12 & 18 & 18 \\
\hline Highest grade in school & & & & & & & & & & \\
\hline Illiterate (did not attend school) & 0 & 0 & 0 & 0 & 1 & 4 & 0 & 0 & 1 & 1 \\
\hline Primary & 0 & 0 & 0 & 0 & 6 & 24 & 1 & 4 & 7 & 7 \\
\hline Intermediate & 0 & 0 & 0 & 0 & 6 & 24 & 2 & 8 & 8 & 8 \\
\hline High school & 9 & 36 & 22 & 88 & 5 & 20 & 4 & 16 & 40 & 40 \\
\hline Diploma & 0 & 0 & 0 & 0 & 1 & 4 & 3 & 12 & 4 & 4 \\
\hline College & 8 & 32 & 2 & 8 & 3 & 12 & 5 & 20 & 18 & 18 \\
\hline Postgraduate & 8 & 32 & 1 & 4 & 3 & 12 & 10 & 40 & 22 & 22 \\
\hline Household annual income (Saudi & & & & & & & & & & \\
\hline Less than 50000 & 5 & 20 & 6 & 24 & 2 & 8 & 1 & 4 & 14 & 14 \\
\hline $50000-<100000$ & 0 & 0 & 2 & 8 & 5 & 20 & 4 & 16 & 11 & 11 \\
\hline $100000-<150000$ & 4 & 16 & 9 & 36 & 4 & 16 & 2 & 8 & 19 & 19 \\
\hline $150000-<200000$ & 2 & 8 & 4 & 16 & 4 & 16 & 5 & 20 & 15 & 15 \\
\hline $200000-<250000$ & 3 & 12 & 2 & 8 & 4 & 16 & 1 & 4 & 10 & 10 \\
\hline More than 250000 & 11 & 44 & 2 & 8 & 6 & 24 & 12 & 48 & 31 & 31 \\
\hline Current occupation & & & & & & & & & & \\
\hline Student & 9 & 36 & 23 & 92 & 0 & 0 & 0 & 0 & 32 & 32 \\
\hline Unemployed & 2 & 8 & 0 & 0 & 16 & 64 & 2 & 8 & 20 & 20 \\
\hline Employed & 14 & 56 & 1 & 4 & 1 & 4 & 5 & 20 & 21 & 21 \\
\hline Self-employed & 0 & 0 & 1 & 4 & 1 & 4 & 4 & 16 & 6 & 6 \\
\hline Retired & 0 & 0 & 0 & 0 & 7 & 28 & 14 & 56 & 21 & 21 \\
\hline
\end{tabular}

†Sisha/argela consists of tobacco, molasses or honey and dried fruits.

Table 3 Mean daily intakes of zinc, phytic acid and protein assessed by the first administration of the FFQ (FFQ1), the $3 d$ food record (FR) and the second administration of the FFQ (FFQ2) among males and females aged 20-30 years and 60-70 years, Jeddah, Saudi Arabia (n 100)

\begin{tabular}{|c|c|c|c|c|c|c|c|}
\hline \multirow[b]{2}{*}{ Item } & \multirow{2}{*}{$\frac{\text { FFQ1 }}{\text { Mean }}$} & \multirow{2}{*}{$\begin{array}{c}\text { FR } \\
\text { Mean }\end{array}$} & \multicolumn{2}{|c|}{$95 \% \mathrm{Cl}$ of the difference } & \multirow{2}{*}{$\frac{\text { FFQ2 }}{\text { Mean }}$} & \multicolumn{2}{|c|}{$95 \% \mathrm{Cl}$ of the difference } \\
\hline & & & Lower & Upper & & Lower & Upper \\
\hline $\begin{array}{l}\text { Zn }(\mathrm{mg} / \mathrm{d}) \\
\text { Phytic acid }(\mathrm{mg} / \mathrm{d}) \\
\text { Protein }(\mathrm{g} / \mathrm{d})\end{array}$ & $\begin{array}{l}10 \cdot 6 \\
521 \\
76 \cdot 4\end{array}$ & $\begin{array}{l}8 \cdot 2^{\star \star \star} \\
511 \\
68 \cdot 7^{\star}\end{array}$ & $\begin{array}{r}1.52 \\
-61.93 \\
1.66\end{array}$ & $\begin{array}{r}3.18 \\
80.94 \\
13 \cdot 77\end{array}$ & $\begin{array}{l}10 \cdot 0^{*} \\
495 \\
72 \cdot 9^{*}\end{array}$ & $\begin{array}{r}0.08 \\
-7.92 \\
0.16\end{array}$ & $\begin{array}{r}1.08 \\
60.77 \\
6.92\end{array}$ \\
\hline
\end{tabular}

Mean values are significantly different from those of FFQ1: ${ }^{\star} P<0.05,{ }^{\star \star \star} P<0.001$.

tPaired differences between FFQ1 and FR.

†Paired differences between FFQ1 and FFQ2.

and $P=0 \cdot 013$, respectively). In contrast, there were no statistically significant differences between estimates obtained by FFQ1 and the FR for the mean intake of phytic acid $(P=0 \cdot 792)$. Significant correlation coefficients were found between $\mathrm{Zn}$ and protein intakes obtained from FFQ1 and the FR (Table 4). 
Table 4 Spearman correlation coefficients $(r)$ between intakes estimated from the first administration of the FFQ (FFQ1) and the $3 \mathrm{~d}$ food record (FR; validity) and between FFQ1 and the second administration of the FFQ (FFQ2; repeatability) among males and females aged $20-30$ years and $60-70$ years, Jeddah, Saudi Arabia ( $n$ 100)

\begin{tabular}{lcc}
\hline Item & $\begin{array}{c}r \text { between FFQ1 } \\
\text { and FR }\end{array}$ & $\begin{array}{c}r \text { between FFQ1 } \\
\text { and FFQ2 }\end{array}$ \\
\hline Zn $(\mathrm{mg} / \mathrm{d})$ & $0.410^{\star \star \star}$ & $0.758^{\star \star \star}$ \\
Phytic acid $(\mathrm{mg} / \mathrm{d})$ & 0.110 & $0.628^{\star \star \star}$ \\
Protein $(\mathrm{g} / \mathrm{d})$ & $0.429^{\star \star \star}$ & $0.799^{\star \star \star}$ \\
\hline
\end{tabular}

Significance of the correlation: ${ }^{\star \star *} P<0.001$.

Bland-Altman analysis was performed to reveal if use of FFQ1 compared with the $3 \mathrm{~d}$ FR resulted in any bias in measured intake values across the range of values and to obtain values for limits of agreement between the two methods. For this purpose, the differences in the estimates of $\mathrm{Zn}$, protein and phytic acid intake between the two methods (FR - FFQ1) were plotted as a function of the mean $\mathrm{Zn}$, phytic acid and protein intakes estimated by the two methods (FFQ1 + FR)/2). Limits of agreement and mean differences, respectively, were: for $\mathrm{Zn},-10 \cdot 6$ to +5.9 , mean difference $-2.3 \mathrm{mg} / \mathrm{d}$ (Fig. 1(a)); for phytic acid, -715 to +696 , mean difference $-9.5 \mathrm{mg} / \mathrm{d}$ (Fig. 1(b)); for protein -67.5 to $+52 \cdot 1$, mean difference $-7.7 \mathrm{~g} / \mathrm{d}$ (Fig. 1(c)). For zinc and phytic acid, the difference in intake estimated by FFQ1 and the FR increased with increasing mean intake (Fig. 1(a) and (b), respectively). However, the difference in protein intake as measured by the two different methods was consistent across the full range of intakes (Fig. 1(c)).

The extent of agreement between measurement methods in classifying individuals into the same or extreme tertiles of the intake distribution is shown in Table 5. The proportion of participants correctly categorized in the same tertile ranged from $55 \%$ (phytic acid) to $62 \%(\mathrm{Zn})$. $\mathrm{Zn}$ and protein intakes showed the lowest proportion of misclassification ( $2 \%$ ), whereas the highest degree of misclassification was observed for phytic acid intake (8\%).

\section{Repeatability}

We assessed the repeatability of the FFQ by comparing data collected using FFQ1 and data collected using the second administration of the same FFQ, FFQ2 (Table 3). Daily $\mathrm{Zn}$ and protein intakes from FFQ2 were slightly but significantly lower than those from FFQ1 by $\sim 0.5 \mathrm{mg}$ and $\sim 4 \mathrm{~g}(P=0.024$ and $P=0.040)$, respectively, whereas estimates of phytic acid intake were not significantly different $(P=0.130)$. Intakes of $\mathrm{Zn}$, phytic acid and protein from FFQ1 and FFQ2 were highly correlated (Table 4).

Figure 2 presents the limits of agreement and the mean differences in estimated dietary intakes obtained from FFQ1 and FFQ2. For all dietary components, the limits of agreement were narrower than those obtained for the comparison between FFQ1 and FR. For $\mathrm{Zn}$ and protein,
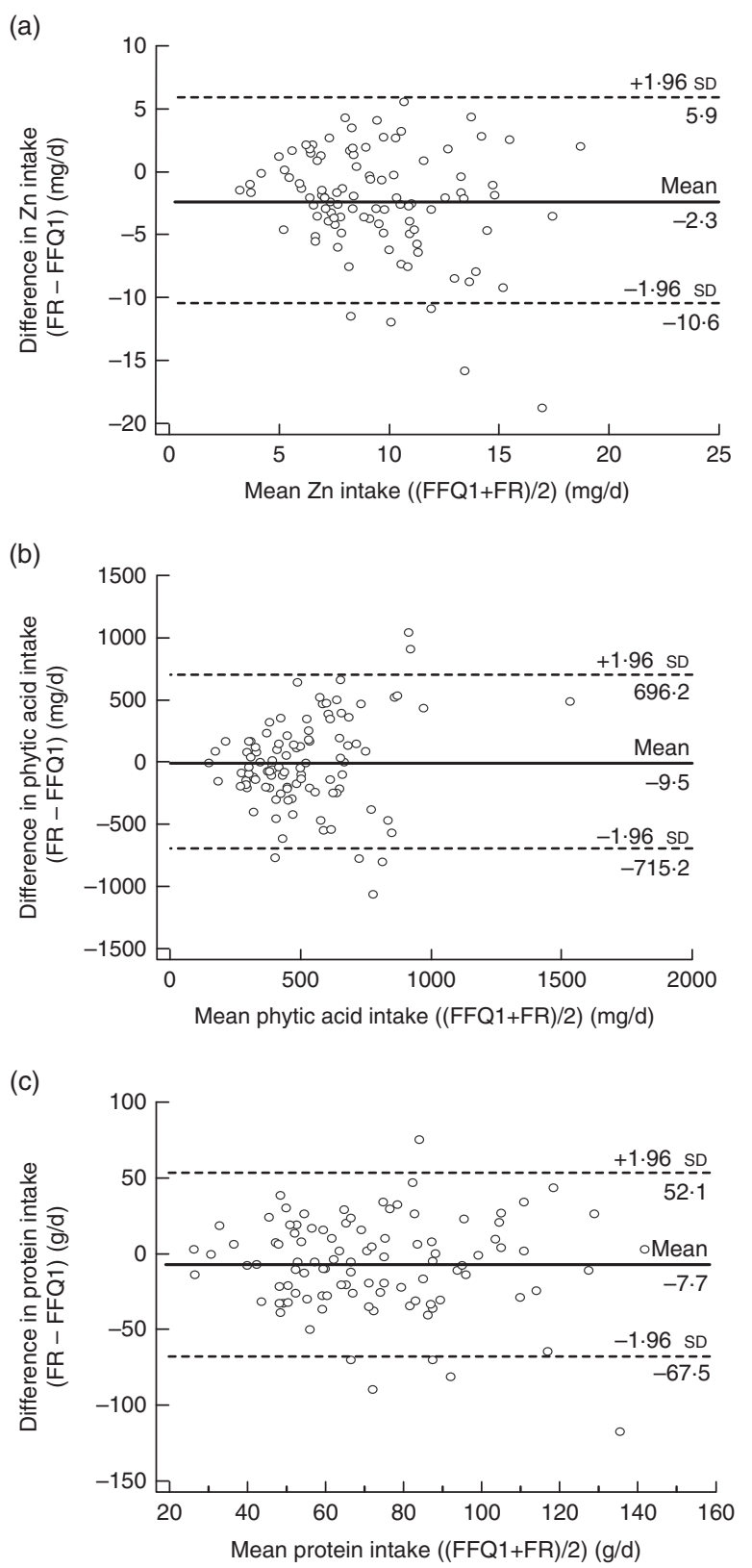

Fig. 1 Bland-Altman plots showing the relationship between the differences in daily intake of (a) zinc, (b) phytic acid and (c) protein estimated by the first administration of the FFQ (FFQ1) and the $3 \mathrm{~d}$ food record (FR) and the corresponding mean daily intakes estimated by the two methods; males and females aged 20-30 years and 60-70 years, Jeddah, Saudi Arabia ( $n$ 100). represents the mean difference and --.---- represent the lower and upper $95 \%$ limits of agreement

the mean differences between the two FFQ were smaller, and for phytic acid the mean difference was larger, than those obtained between FFQ1 and FR.

\section{Effects of age and gender on intakes of $\mathrm{Zn}$ and Zn-absorption modifiers in Saudi adults}

The mean intakes by age and gender age groups estimated using each of the two methods are displayed in Table 6. 
Table 5 Cross-classification of daily intakes derived from the first administration of the FFQ (FFQ1) and the $3 \mathrm{~d}$ food record (FR) among males and females aged $20-30$ years and $60-70$ years, Jeddah, Saudi Arabia ( $n$ 100)

\begin{tabular}{lcc}
\hline Item & $\begin{array}{c}\text { Correctly classified } \\
(\text { same tertile }) \\
(\%)\end{array}$ & $\begin{array}{c}\text { Grossly misclassified } \\
\text { (extreme tertiles) } \\
(\%)\end{array}$ \\
\hline Zn $(\mathrm{mg} / \mathrm{d})$ & 62 & 2 \\
Phytic acid $(\mathrm{mg} / \mathrm{d})$ & 55 & 8 \\
Protein $(\mathrm{g} / \mathrm{d})$ & 57 & 2 \\
\hline
\end{tabular}

Irrespective of whether measured using FFQ1 or the $3 \mathrm{~d}$ FR, we observed that young adults consumed more $\mathrm{Zn}$ and protein than older adults. There were no detectable effects of age on phytic acid intake by either dietary assessment method. In contrast, for other dietary components, differences in intakes between groups were statistically significant only when measured by the FR. Intake of phytic acid was $100 \mathrm{mg}$ higher in males than females $(P=0 \cdot 033)$. Females consumed $\sim 2 \mathrm{mg}$ less $\mathrm{Zn}$ daily than males $(P=0.002)$. Similarly, females' intake of protein was lower, by approximately $\sim 22 \mathrm{~g} / \mathrm{d}$, than that of males $(P<0 \cdot 001)$

Both FFQ indicated that older adults consumed less $\mathrm{Zn}$ and protein than young adults $(P=0.002$ and $P=0.006$, respectively; Table 6 ). Other differences in intakes between groups were statistically significant only when measured by FFQ2. We observed that males consumed more $\mathrm{Zn}$ and protein than females $(P=0.021$ and $P=0 \cdot 045$, respectively).

\section{Discussion}

The sixty-four-item FFQ developed for the present study was used successfully to obtain estimates of intakes of $\mathrm{Zn}$, protein and phytic acid by all 100 young and older Saudi adult participants.

\section{Relative validity}

The FFQ yielded higher estimates of $\mathrm{Zn}$ intake than were obtained from the FR. A similar difference in estimates of $\mathrm{Zn}$ intake between a seventy-four-item FFQ and a $7 \mathrm{~d}$ weighed record was also reported by Samman et al. ${ }^{(29)}$. Although FFQ can both under- and overestimate nutrient intake, many validation studies have reported that FFQ overestimate nutrient intakes when compared with FR or $24 \mathrm{~h}$ recalls ${ }^{(34-36)}$. Of course, whether estimates of intake obtained using an FR are reliable cannot be known with certainty, but it is evident that our FFQ yielded consistently higher estimates of $\mathrm{Zn}$ intake than did the FR (as confirmed by Bland-Altman analysis). A potential reason for this difference is the inclusion within the FFQ of a relatively large number of food items focusing on specific dietary components of interest, which may lead to overestimates
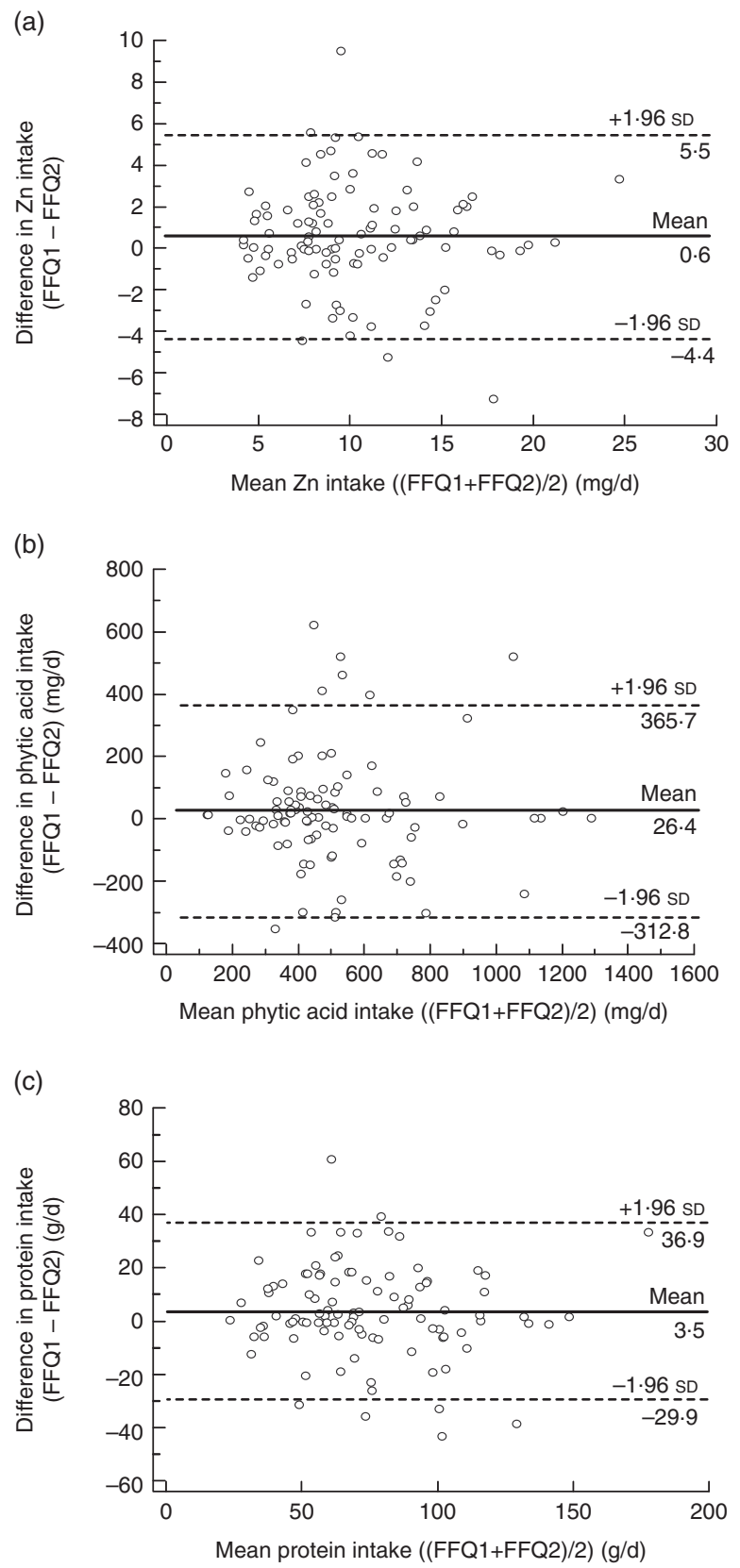

Fig. 2 Bland-Altman plots showing the relationship between the differences in daily intake of (a) zinc, (b) phytic acid and (c) protein estimated by the first administration of the FFQ (FFQ1) and the second administration of the FFQ (FFQ2) and the corresponding mean daily intakes estimated by the two methods; males and females aged 20-30 years and 60-70 years, Jeddah, Saudi Arabia ( $n$ 100). mean difference and -------- represent the lower and upper $95 \%$ limits of agreement

of intakes. Other factors include measurement errors caused by over-reporting of frequency of food consumption and serving sizes ${ }^{(34)}$ and decreases in participants' accuracy toward the end of the questionnaire.

The correlation coefficients observed between the FFQ and FR for estimates of $\mathrm{Zn}$, phytic acid and protein intakes 
Table 6 Mean daily intakes of zinc, phytic acid and protein estimated by the first administration of the FFQ (FFQ1), the $3 \mathrm{~d}$ food record (FR) and the second administration of the FFQ (FFQ2), according to age and gender groups, among males and females aged 20-30 years and 60-70 years, Jeddah, Saudi Arabia $(n 100)$

\begin{tabular}{|c|c|c|c|c|c|c|c|c|}
\hline & \multicolumn{2}{|c|}{ Males } & \multicolumn{2}{|c|}{ Females } & \multirow[b]{2}{*}{ Pooled SE } & \multicolumn{3}{|c|}{ Probability of effect } \\
\hline & Young & Older & Young & Older & & Age & Gender & Age $\times$ gender \\
\hline \multicolumn{9}{|l|}{ FFQ1 } \\
\hline $\mathrm{Zn}(\mathrm{mg} / \mathrm{d})$ & $12 \cdot 9$ & 9.5 & $10 \cdot 6$ & 9.3 & 0.81 & 0.005 & 0.126 & 0.157 \\
\hline Phytic acid (mg/d) & 566 & 464 & 567 & 488 & 48.54 & 0.065 & 0.80 & 0.813 \\
\hline Protein $(g / d)$ & 92.6 & $68 \cdot 8$ & $75 \cdot 0$ & $69 \cdot 1$ & $5 \cdot 71$ & 0.011 & 0.138 & 0.12 \\
\hline \multicolumn{9}{|l|}{ FR } \\
\hline $\mathrm{Zn}(\mathrm{mg} / \mathrm{d})$ & $10 \cdot 2$ & $8 \cdot 2$ & $7 \cdot 6$ & 6.9 & 0.63 & 0.037 & 0.002 & 0.271 \\
\hline Phytic acid (mg/d) & 579 & 574 & 458 & 436 & 59.92 & 0.827 & 0.033 & 0.891 \\
\hline Protein (g/d) & 88.4 & 71.4 & $59 \cdot 4$ & 55.5 & 5.04 & 0.041 & 0.00 & 0.195 \\
\hline \multicolumn{9}{|l|}{ FFQ2 } \\
\hline $\mathrm{Zn}(\mathrm{mg} / \mathrm{d})$ & $12 \cdot 6$ & $9 \cdot 3$ & $10 \cdot 0$ & 8.0 & 0.82 & 0.002 & 0.021 & 0.375 \\
\hline Phytic acid (mg/d) & 555 & 477 & 520 & 428 & $49 \cdot 16$ & 0.085 & 0.395 & 0.886 \\
\hline Protein $(\mathrm{g} / \mathrm{d})$ & $89 \cdot 8$ & 67.9 & $72 \cdot 6$ & $61 \cdot 1$ & 5.90 & 0.006 & 0.045 & 0.376 \\
\hline
\end{tabular}

compare favourably with those reported in other studies using the same reference method (multiple days of FR) ${ }^{(37-40)}$. The higher correlations between methods reported by Samman et al. ${ }^{(29)}$ and Heath et al. ${ }^{(41)}$ may result from the use of a different reference instrument, i.e. weighed diet records rather than estimated FR.

In the present study, the limits of agreement between the FFQ and the FR and the mean difference between them were not unreasonable for any dietary component measured. When compared with the results obtained by Samman et al. ${ }^{(29)}$, the limits of agreement between the two methods in estimating $\mathrm{Zn}$ intake were wider and the mean difference was slightly higher. Conversely, our estimate of the limits of agreement for protein intake was narrower than that reported by Pakseresht and Sharma ${ }^{(42)}$ and the mean difference was lower. The authors of the latter study chose the $24 \mathrm{~h}$ recall as a reference method, which shares with the FFQ some of the same sources of potential measurement error including recall bias, conceptualization of portion sizes and distortion of reported diet ${ }^{(37)}$. Bland-Altman plots of phytic acid intake showed that the agreement between the two methods was better for participants with lower phytic acid intake. This indicates that participants with higher intakes may be over-reporting their intake in the $\mathrm{FFQ}^{(42)}$ or that the FR method does not capture accurately the intakes of high consumers. To our knowledge, the present study is the first one to use Bland-Altman analysis to evaluate estimates of phytic acid intake. The cross-classification analysis revealed that more than $50 \%$ of participants were correctly classified into the same third, and less than $10 \%$ were misclassified into opposite thirds, of dietary component intakes. These results are in line with recommendations ${ }^{(43)}$ and consistent with other studies assessing the ability of FFQ and FR to classify nutrient intakes into tertiles $^{(38,40)}$. The favourable tertile classifications that were obtained suggest that our FFQ is suitable for ranking individuals correctly according to their nutrient intake.

\section{Repeatability}

Several studies have reported lower estimates of nutrient intake when an FFQ was used a second time with the same participants ${ }^{(37,40)}$. In our study, intake estimates with FFQ2 were consistently lower than with FFQ1 but the differences were small for $\mathrm{Zn}$ and for the $\mathrm{Zn}$-absorption modifiers investigated (1.0-5.5\% only; Table 3$)$. Barrat et $a l .{ }^{(37)}$ suggested that such decreases may be due, in part, to a learning effect (i.e. participants responded more accurately in the second FFQ and thus real dietary habits were reflected). Alternatively, the chore of completing the FFQ on a second or subsequent occasion may lead to less careful completion of the questionnaire. None the less, Lee et $a l .{ }^{(40)}$ found that correlations between the first FFQ and the best estimate from dietary records were slightly lower than those between a third application of the FFQ and the dietary records, confirming the possibility of a learning effect $^{(37)}$. This trend is confirmed by findings from the present study in which correlations between the second FFQ and the FR were slightly higher than those obtained from the first FFQ (results not shown).

Correlations coefficients between FFQ1 and FFQ2, observed in the current study, were very similar to those reported in a short-term repeatability study by Barrat et $a{ }^{(37)}$ and slightly higher than those reported by Jia et $a .^{(44)}$, Barrett and Gibson ${ }^{(38)}$, Alissa ${ }^{(25)}$, FernandezBallart et $a l .{ }^{(45)}$ and Lee et $a l .{ }^{(40)}$. It should be noted that the time periods between the two FFQ in the latter studies were longer (from 3 months up to 1 year, compared with 1 month in the present study), which increased the likelihood of real changes in dietary habits and thus reduced correlation coefficients ${ }^{(37)}$.

\section{Effects of age and gender on intakes of $\mathrm{Zn}$ and Zn-absorption modifiers in Saudi adults}

The mean daily $\mathrm{Zn}$ intake assessed by the FFQ $(10.6 \mathrm{mg})$ is very similar to the mean values $(10.50 \mathrm{mg})$ obtained by Samman et al. ${ }^{(29)}$ in Australia and Alissa ${ }^{(25)}(10 \cdot 23 \mathrm{mg})$ in 
Saudi Arabia but substantially lower than that reported by Barrett and Gibson ${ }^{(38)}$ (15.3 mg) for Australian participants using an FFQ method. The mean phytic acid intake of Saudi adults $(521.33 \mathrm{mg})$ was lower than intake of British $(917 \mathrm{mg})^{(46)}$ and New Zealand adults $(1498 \mathrm{mg})^{(41)}$ when using a 4-7d weighed intake method and FFQ, respectively. The mean daily intake of protein was $76.4 \mathrm{~g}$, which is comparable with the result of another Saudi study $(72.53 \mathrm{~g})^{(25)}$ and lower than those reported in Taiwanese $(87 \mathrm{~g})^{(40)}$, Spanish $(103 \cdot 1 \mathrm{~g})^{(45)}$ and Australian $(105 \cdot 9 \mathrm{~g})^{(38)}$ studies when using FFQ methods.

Several studies found that mean $\mathrm{Zn}$ and protein intakes were lower in older adults than young adults when estimated by various dietary methods (e.g. FFQ and $24 \mathrm{~h}$ recall), in agreement with our findings irrespective of the method of measurement ${ }^{(25,47)}$. Lower intakes of phytic acid, $\mathrm{Zn}$ and protein in women than in men as observed in our study have been reported previously by McDaid et $a l .{ }^{(48)}$, Amirabdollahian and Ash ${ }^{(27)}$, Coulibaly et al. ${ }^{(49)}$ and Adamson et al. ${ }^{(47)}$. These differences may due to differences in energy intake between the age and gender groups; we observed that total energy intake was lower in older than in young adults and in female than male participants (data not shown).

\section{Strengths and limitations}

The use of an FFQ reduces the burden associated with dietary intake estimation for both study participants and researchers. Such an approach may be particularly useful in some cultural settings because it lowers the cognitive complexity and difficulty for participants not involved in cooking. Since including too few items has been shown to lead to underestimation of intake using an $\mathrm{FFQ}^{(32)}$, the present study used a relatively large number of food items (sixty-four) to assess intake of $\mathrm{Zn}$ and its absorption modifiers. Additionally, we used a relatively large number of frequency categories to reduce participants' frustration if unable to find the correct response ${ }^{(32)}$. However, in common with all conventional approaches to estimating dietary intake, FFQ have potential limitations due to subjectivity in intake recording ${ }^{(50)}$. Newer developments, including the use of metabolomics approaches, may provide more objective estimates of dietary exposure ${ }^{(51)}$. The participants recruited to the study were a convenience sample and were not intended to be representative of the whole Saudi population. This limitation should be borne in mind when considering any extrapolation of the data obtained beyond the parameters of this study population.

\section{Conclusion}

The FFQ developed and tested in the present study demonstrated reasonable relative validity and high repeatability in estimating and ranking intakes of $\mathrm{Zn}$, phytic acid and protein of Saudi adults living in the western region of Saudi Arabia and is likely to have wide utility in epidemiological and population surveys. Its use demonstrated clear gender- and age-related differences in $\mathrm{Zn}$ intake and in intakes of $\mathrm{Zn}$-absorption modifiers in this convenience population sample, which may have implications for $\mathrm{Zn}$ status and health particularly among older people.

\section{Acknowledgements}

Acknowledgements: The authors are grateful to all of the volunteers who participated in the study. Financial support: This work was supported by the Joint Supervision Program (JSP), King Abdulaziz University, Jeddah, Saudi Arabia. JSP had no role in the design, analysis or writing of this article. Conflict of interest: None. Authorship: As part of a $\mathrm{PhD}$ research programme, H.A.M. designed the study, worked in all stages of data collection and analysis, and wrote the manuscript. F.Y. collected data. T.K., D.F. and J.C.M were responsible for supervising the project, designed the study, contributed to interpretation of the data and reviewed the draft. Ethics of human subject participation: This project was approved by the research ethical committee at King Abdulaziz University, Jeddah, Saudi Arabia.

\section{References}

1. Cousins RJ (1998) A role of zinc in the regulation of gene expression. Proc Nutr Soc 57, 307-311.

2. Andreini C, Banci L, Bertini I et al. (2006) Counting the zincproteins encoded in the human genome. J Proteome Res $\mathbf{5}$, 196-201.

3. Berdanier C \& Zempleni J (2009) Advanced Nutrition: Macronutrients, Micronutrients and Metabolism. New York: CRC Press.

4. Prasad AS (2009) Zinc: role in immunity, oxidative stress and chronic inflammation. Curr Opin Clin Nutr Metab Care 12, 646-652.

5. Haas C, Rodionov D, Kropat J et al. (2009) A subset of the diverse COG0523 family of putative metal chaperones is linked to zinc homeostasis in all kingdoms of life. $B M C$ Genomics 10, 470.

6. Yamaguchi M (1998) Role of zinc in bone formation and bone resorption. J Trace Elem Exp Med 11, 119-135.

7. Wright A, King J, Baer M et al. (1981) Experimental zinc depletion and altered taste perception for $\mathrm{NaCl}$ in young adult males. Am J Clin Nutr 34, 848-852.

8. Keast RSJ (2003) The effect of zinc on human taste perception. J Food Sci 68, 1871-1877.

9. Yamaguchi S, Miura C, Kikuchi K et al. (2009) Zinc is an essential trace element for spermatogenesis. Proc Natl Acad Sci USA 106, 10859-10864.

10. Rostan E, DeBuys H, Madey D et al. (2002) Evidence supporting zinc as an important antioxidant for skin. Int $J$ Dermatol 41, 606-611.

11. Powell SR (2000) The antioxidant properties of zinc. J Nutr 130, 5 S Suppl., 1447S-1454S.

12. Fukada T, Yamasaki S, Nishida K et al. (2011) Zinc homeostasis and signaling in health and diseases: zinc signaling. J Biol Inorg Chem 16, 1123-1134. 
13. Krebs NF (2000) Overview of zinc absorption and excretion in the human gastrointestinal tract. J Nutr 130, 5 S Suppl., 1374S-1377S.

14. Lee HH, Prasad AS, Brewer GJ et al. (1989) Zinc absorption in human small intestine. Am J Physiol 256, G87-G91.

15. Seal CJ \& Mathers JC (1989) Intestinal zinc transfer by everted gut sacs from rats given diets containing different amounts and types of dietary fibre. BrJ Nutr 62, 151-163.

16. Sandstrom B, Arvidsson B, Cederblad A et al. (1980) Zinc absorption from composite meals. I. The significance of whest extraction rate, zinc, calcium, and protein content in meals based on bread. Am J Clin Nutr 33, 739-745.

17. Couzy F, Mansourian R, Labate A et al. (1998) Effect of dietary phytic acid on zinc absorption in the healthy elderly, as assessed by serum concentration curve tests. Br J Nutr 80, 177-182.

18. Kim J, Paik HY, Joung H et al. (2007) Effect of dietary phytate on zinc homeostasis in young and elderly Korean women. J Am Coll Nutr 26, 1-9.

19. Hunt JR \& Beiseigel JM (2009) Dietary calcium does not exacerbate phytate inhibition of zinc absorption by women from conventional diets. Am J Clin Nutr 89, 839-843.

20. Lonnerdal B (2000) Dietary factors influencing zinc absorption. J Nutr 130, 5 S Suppl., 1378S-1383S.

21. Gibson RS (2005) Principles of Nutritional Assessment, 2nd ed. New York: Oxford University Press.

22. Coneyworth LJ, Mathers JC \& Ford D (2009) Does promoter methylation of the SLC30A5 (ZnT5) zinc transporter gene contribute to the ageing-related decline in zinc status? Proc Nutr Soc 68, 142-147.

23. Kumosani T, Abdul-Jabar H \& Al-Tazi Z (1997) Serum zinc level of healthy individuals living in western province of Saudi Arabia. Ain Shams Med J 48, 797-802.

24. Al-Numair K (2006) Copper and zinc status in healthy volunteers living in Saudi Arabia. J Med Sci 6, 519-527.

25. Alissa E (2005) Microntrients status and atherosclerosis. PhD Thesis, University of Surrey.

26. Sadiq E (2005) Study on the effect of food pattern and food habits on the nutritional status of elderly women in Jeddah. Masters Thesis, King Abdulaziz University.

27. Alenezy F (2003) Nutritional status assessment of the elderly in the northern province of Saudi Arabia. Masters Thesis, King Saud University.

28. Lee RD \& Nieman DC (2010) Nutritional Assessment, 5th ed. New York: McGraw-Hill.

29. Samman S, Herbert J, Petocz P et al. (2010) Development and validation of a short questionnaire for estimating the intake of zinc. Biol Trace Elem Res 134, 226-234.

30. Almuhaizie IS \& Albehairy MM (2003) Development of Nutritional Status in Kingdom of Saudi Arabia During the Past Two Decades 1402-1422 H. Riyadh, Saudi Arabia: Academic Publishing and Press, King Saud University.

31. Musaiger A (2006) Food Composition Tables for Arab Gulf Countries (GULFOODS). Manama, Bahrain: Arab Center for Nutrition.

32. Cade J, Thompson R, Burley V et al. (2002) Development, validation and utilisation of food-frequency questionnaires a review. Public Health Nutr 5, 567-587.

33. Nelson M, Atkinson M \& Meyer J (1997) A Photographic Atlas of Food Portion Sizes. London: Ministry of Agriculture, Fisheries and Food.

34. Segovia-Siapco G, Singh P, Jaceldo-Siegl K et al. (2007) Validation of a food-frequency questionnaire for measurement of nutrient intake in a dietary intervention study. Public Health Nutr 10, 177-184.

35. Sebring NG, Denkinger BI, Menzie CM et al. (2007) Validation of three food frequency questionnaires to assess dietary calcium intake in adults. J Am Diet Assoc 107, 752-759.

36. Schaefer EJ, Augustin JL, Schaefer MM et al. (2000) Lack of efficacy of a food-frequency questionnaire in assessing dietary macronutrient intakes in subjects consuming diets of known composition. Am J Clin Nutr 71, 746-751.

37. Barrat E, Aubineau N, Maillot M et al. (2012) Repeatability and relative validity of a quantitative food-frequency questionnaire among French adults. Food Nutr Res 2012, 56.

38. Barrett JS \& Gibson PR (2010) Development and validation of a comprehensive semi-quantitative food frequency questionnaire that includes FODMAP intake and glycemic index. J Am Diet Assoc 110, 1469-1476.

39. Na YJ \& Lee SH (2012) Development and validation of a quantitative food frequency questionnaire to assess nutritional status in Korean adults. Nutr Res Pract 6, 444-450.

40. Lee MS, Pan WH, Liu KL et al. (2006) Reproducibility and validity of a Chinese food frequency questionnaire used in Taiwan. Asia Pac J Clin Nutr 15, 161-169.

41. Heath AL, Skeaff CM \& Gibson RS (2000) The relative validity of a computerized food frequency questionnaire for estimating intake of dietary iron and its absorption modifiers. Eur J Clin Nutr 54, 592-599.

42. Pakseresht M \& Sharma S (2010) Validation of a culturally appropriate quantitative food frequency questionnaire for Inuvialuit population in the Northwest Territories, Canada. J Hum Nutr Diet 23, Suppl. 1, 75-82.

43. Masson LF, McNeill G, Tomany JO et al. (2003) Statistical approaches for assessing the relative validity of a foodfrequency questionnaire: use of correlation coefficients and the kappa statistic. Public Health Nutr 6, 313-321.

44. Jia X, Craig LC, Aucott LS et al. (2008) Repeatability and validity of a food frequency questionnaire in free-living older people in relation to cognitive function. $J$ Nutr Health Aging 12, 735-741.

45. Fernandez-Ballart JD, Pinol JL, Zazpe I et al. (2010) Relative validity of a semi-quantitative food-frequency questionnaire in an elderly Mediterranean population of Spain. Br J Nutr 103, 1808-1816.

46. Amirabdollahian F \& Ash R (2010) An estimate of phytate intake and molar ratio of phytate to zinc in the diet of the people in the United Kingdom. Public Health Nutr 13, 1380-1388.

47. Adamson AJ, Collerton J, Davies K et al. (2009) Nutrition in advanced age: dietary assessment in the Newcastle 85+ study. Eur J Clin Nutr 63, Suppl. 1, S6-S18.

48. McDaid O, Stewart-Knox B, Parr H et al. (2007) Dietary zinc intake and sex differences in taste acuity in healthy young adults. J Hum Nutr Diet 20, 103-110.

49. Coulibaly A, Turgeon O'Brien H \& Galibois I (2009) Validation of an FFQ to assess dietary protein intake in type 2 diabetic subjects attending primary health-care services in Mali. Public Health Nutr 12, 644-650.

50. Penn L, Boeing H, Boushey C et al. (2010) Assessment of dietary intake: NuGO symposium report. Genes Nutr $\mathbf{5}$, 205-213.

51. Fave G, Beckmann M, Lloyd AJ et al. (2011) Development and validation of a standardized protocol to monitor human dietary exposure by metabolite fingerprinting of urine samples. Metabolomics 7, 469-484. 